\title{
Financial Health \& Corporate Performance - a Comparison of Manufacturing Companies in China \& India
}

\author{
Foo See Liang (Corresponding author) \\ School of Accountancy, Singapore Management University \\ 60 Stamford Road, 178900 Singapore \\ Tel: 6828-0966Ｅ-mail: slfoo@smu.edu.sg \\ Shaakalya Pathak \\ E-mail: shaakalyap.2011@smu.edu.sg
}

Received: April 2, 2016 Accepted: April 18, 2016 Published: May 3, 2016

doi:10.5296/jad.v2i1.9414 URL: http://dx.doi.org/10.5296/jad.v2i1.9414

\begin{abstract}
The People's Republic of China (China) and India are two leading economies in Asia Pacific. This study examines the relationship between the financial health, as measured by the Altman Z-Score, and corporate performance, as measured by the Return on Equity (ROE), of listed manufacturing companies in these two markets. A linear regression was conducted between these variables to determine the magnitude and direction of their relationships. The trends of Z-Scores over a fourteen-year period are also analysed. The analysis covers the period from 2000 to 2013 (inclusive) and yielded a statistically positive correlation between ROE and the Z-Score for both markets. China and India both registered moderate-to-strong mean and median Z-Scores. However, China is comparatively healthier. These findings further support the economic stature of these two markets as Asian giants.
\end{abstract}

Keywords: Financial Health, Corporate Performance, Manufacturing, Altman Z-Score, Return on Equity

\section{Introduction}

The Asia Pacific region has experienced dramatic economic growth in recent years (Cohen, 2006). While growth is essential, the sustainability of organizations is also dependent on its financial health. Two notable important economies that are riding on these economic growth 
trends are China and India. These two economies are important business hubs in the Asia Pacific economic ecosystem. They are competing for international investment and business opportunities.

The purpose of this paper is to examine the relationship between corporate financial health, as measured by the Altman Z-Score (Altman, 1968), and corporate performance, as measured by the Return on Equity (ROE), of listed manufacturing companies on the Shanghai Stock Exchange (SSE) and the Bombay Stock Exchange (BSE) which are the largest exchanges in China and India. More specifically, we seek to determine whether financial health is a determinant of corporate performance.

\section{Brief Literature Review}

Corporate financial health has been widely studied on countries in the Asia Pacific. These studies include Hong Kong and Singapore (Foo, 2015), China (Wang and Campbell, 2010A and 2010B), India (Pradhan, 2014), Sri Lanka (Gunathilaka, 2014), and Malaysia (Thai, Goh, Teh, Wong and Ong, 2014). The Altman Z-Score (Altman, 1968) was the preferred measure of financial health in these studies.

Unlike the prior model by Beaver (Beaver, 1966) which examined financial ratios separately, Edward I. Altman, created the Altman Z-Score (Altman, 1968) which combined a variety of financial ratios into a single score that reflected the likelihood of a firm going into bankruptcy using multiple discriminant analysis (MDA).

The model showed high predictive power on companies facing financial distress, as measured by the Z-Score. The literature on statistical models for bankruptcy prediction is wide-ranging and continues to expand. For example, E. I. Altman, in his lecture (Altman, 2007) quotes 12 new variants of his models. Other studies on financial health that followed the Z-Score Model include Blum (1974), Deakin (1977), Beynon and Peel (2001), Neophytou et al. (2001) and Chung et al. (2008). Some researchers also used logit regression techniques (Ohlson, 1980), recursive partitioning analysis (Frydman et al., 1985) and artificial neural network models (Trippi and Turban, 1996). Nevertheless, Perez (2006) highlighted that MDA is still one of the most popular approaches used for bankruptcy prediction (Agarwal and Taffler, 2007).

Furthermore, Aziz and Dar (2006) appraised 89 studies on prediction of bankruptcy between 1968 and 2003 and found that the multi-variable models, such as the Z-Score model, were the most widely accepted. Additionally, a significant body of research (e.g. Altman and McGough, 1974; Altman, 1982; Levitan and Knoblett, 1985; Koh and Killough, 1990) supports the reliability of the Z-Score for the prediction of financial distress. Recently, Sherbo and Smith's (2013) study concluded that the Z-Score model has stood the test of time and is still highly applicable in today's business environment. In view of the above merits, this study adopts the Altman Z-Score as our measure of financial health. The formula for the model is discussed in the Methodology and Data section of this paper.

There have been numerous measures of corporate performance and profitability. However, the Return on Equity (ROE) has proven to be a consistently robust and popular measure of corporate performance (Chen (1997), Chen (2005), Damodaran (2007), Hagel et al. (2010), 
and Zhao (2013)). ROE is defined as the income produced on equity capital and is calculated by dividing net income by the book value of shareholder's equity (Damodaran, 2007). It is a widely used accounting measure of companies' financial performance in making investment decisions (Stowe, Robinson, Pinto \& McLeavey, 2002). In view of this body of literature, we adopt ROE as our measure of corporate performance in this study.

A key comparative study done between Asia Pacific countries was by Meric, Lentz, Li and Meric (2014). This study examined the financial characteristics (liquidity, turnover ratios, financial leverage, profitability and growth) of manufacturing firms using multivariate analysis. Although it provided useful insights into these markets, this study did not explore the relationship between their corporate performance and their financial health.

\section{Motivation and Contribution}

Corporate performance is important but sound financial health is also needed to ensure sustainability. The motivation of this study is to determine whether well performing companies are financially healthy in these two markets. This study extends the work by Meric, Lents, Li and Meric (2014) on the Asia Pacific markets by providing further understanding into the financial health, as measured by the Z-Score, and corporate performance, as measured by ROE.

An important contribution is to provide empirical insights about these two markets in relation to their firms' Z-Score and ROE over a period of fourteen years, i.e. 2000 to 2013 (inclusive). This study also provides a comparison and examination of the similarities and differences between these two leading economies. We believe this comparative study would contribute to the further understanding of these two markets by key stakeholders, such as investors.

Unlike studies by Sherbo and Smith's (2013), Zhao (2013), Pradhan, (2014), and Thai, Goh, Teh, Wong and Ong (2014) which applied the Z-Score on individual market or jurisdiction, this study explores the comparative relationship between financial performance and corporate health between two leading markets in the Asia Pacific region, namely China and India.

The subprime crisis period is also captured in our analysis and allows us to examine its effect on China and India. With Asia's growing economic importance, the study hopes to serve as catalyst for similar research on other Asian economies.

Additionally, a further motivation has been to extend the authors' previous study on the Singapore and Hong Kong markets (Foo, 2015).

\section{Research Question \& Hypothesis}

The research question for study is: do higher performing listed manufacturing companies (as measured by the ROE - dependent variable) in China and India also exhibit higher financial health (as measured by the Altman Z-Score the independent variable)? The Null Hypothesis is that there is no significant statistical relationship between firm performance and financial health in each market. Whereas, the Alternative Hypothesis is that there is a significant statistical relationship between firm performance and financial health. 


\section{Macrothink}

\section{Methodology and Data}

This study adopts the widely used Altman (1968) Z-Score model (Wang and Campbell, 2010A and 2010B; Pradhan, 2014; Gunathilaka, 2014; Thai, Goh, Teh, Wong and Ong, 2014) to determine financial health. The Z-Score formula is provided in Figure 1.

\section{Equation for Altman's Z-Score Model (1968):}

$$
\mathrm{Z}=1.2 \mathrm{X}_{1}+1.4 \mathrm{X}_{2}+3.3 \mathrm{X}_{3}+0.6 \mathrm{X}_{4}+1 \mathrm{X}_{5}
$$

$\mathrm{X}_{1}=$ Working Capital / Total Assets

$\mathrm{X}_{2}=$ Retained Earnings / Total Assets

$\mathrm{X}_{3}=$ Earnings Before Interest \& Tax (EBIT) / Total Assets

$\mathrm{X}_{4}=$ Market Capitalisation / Total Liabilities

$\mathrm{X}_{5}=$ Sales $/$ Total Assets

Figure 1. Equation for Altman's Z-Score Model (1968)

A linear regression was run using the relevant data with this formula: $Y=\beta_{1} Z_{1}+C$ where $Y$ is the dependent variable, which is the Return on Equity (ROE); $\beta 1$ is the regression coefficient, which provides an indication of the direction and magnitude of the relationship; $\mathrm{Z} 1$ is the independent variable which is the Altman Z-Score and $\mathrm{C}$ is the constant.

The scope of the regression covers the period from 2000 to 2013. The financial statement data used was extracted from the Thomson Reuters DataStream database. Records of all firms listed on the two exchanges that had available error-free information were utilized in the regression analysis. Furthermore, the top and bottom $1 \%$ of the outliers were removed for the regression analysis.

\section{Descriptive Analysis}

Tables 1 and 2 present the mean and median Z-Scores for the markets and Figures 2 and 3 present their respective trends for the fourteen-year period from 2000 to 2013. As per Altman (1968), a Z-Score that is greater than 2.99 indicates strong financial health, as shown in green in the tables. Whereas, a Z-Score that is lower than 1.81 indicates poor financial health, as shown in red. 
Table 1. Mean and Median Z-Scores - China (SSE)

China (SSE)

\begin{tabular}{lccc}
\hline Year & Median & Mean & Std. Dev. \\
\hline $\mathbf{2 0 0 0}$ & 1.31 & 1.74 & 1.69 \\
$\mathbf{2 0 0 1}$ & 1.32 & 1.71 & 1.46 \\
$\mathbf{2 0 0 2}$ & 2.69 & 3.61 & 2.88 \\
$\mathbf{2 0 0 3}$ & 2.46 & 3.24 & 2.73 \\
$\mathbf{2 0 0 4}$ & 2.17 & 2.71 & 2.23 \\
$\mathbf{2 0 0 5}$ & 1.83 & 2.19 & 1.87 \\
$\mathbf{2 0 0 6}$ & 2.11 & 2.64 & 2.42 \\
$\mathbf{2 0 0 7}$ & 3.71 & 5.13 & 4.64 \\
$\mathbf{2 0 0 8}$ & 2.13 & 2.65 & 2.47 \\
$\mathbf{2 0 0 9}$ & 3.03 & 4.30 & 4.39 \\
$\mathbf{2 0 1 0}$ & 3.24 & 4.70 & 4.75 \\
$\mathbf{2 0 1 1}$ & 2.57 & 3.61 & 3.24 \\
$\mathbf{2 0 1 2}$ & 2.55 & 3.54 & 3.28 \\
$\mathbf{2 0 1 3}$ & 2.81 & 3.90 & 3.50 \\
\hline
\end{tabular}

Table 2. Mean and Median Z-Scores - India (BSE)

India (BSE)

\begin{tabular}{lccc}
\hline Year & Median & Mean & Std. Dev. \\
\hline $\mathbf{2 0 0 0}$ & 1.26 & 1.74 & 1.33 \\
$\mathbf{2 0 0 1}$ & 1.29 & 0.97 & 1.28 \\
$\mathbf{2 0 0 2}$ & 0.93 & 1.09 & 0.66 \\
$\mathbf{2 0 0 3}$ & 1.59 & 1.59 & 1.47 \\
$\mathbf{2 0 0 4}$ & 1.57 & 2.09 & 1.89 \\
$\mathbf{2 0 0 5}$ & 1.60 & 2.63 & 3.78 \\
$\mathbf{2 0 0 6}$ & 2.16 & 3.26 & 4.83 \\
$\mathbf{2 0 0 7}$ & 2.27 & 3.84 & 6.85 \\
$\mathbf{2 0 0 8}$ & 2.15 & 3.02 & 3.89 \\
$\mathbf{2 0 0 9}$ & 1.77 & 2.45 & 3.30 \\
$\mathbf{2 0 1 0}$ & 2.19 & 4.21 & 11.18 \\
$\mathbf{2 0 1 1}$ & 1.92 & 3.65 & 8.20 \\
$\mathbf{2 0 1 2}$ & 1.81 & 3.53 & 7.98 \\
$\mathbf{2 0 1 3}$ & 1.93 & 3.78 & 9.74 \\
\hline
\end{tabular}




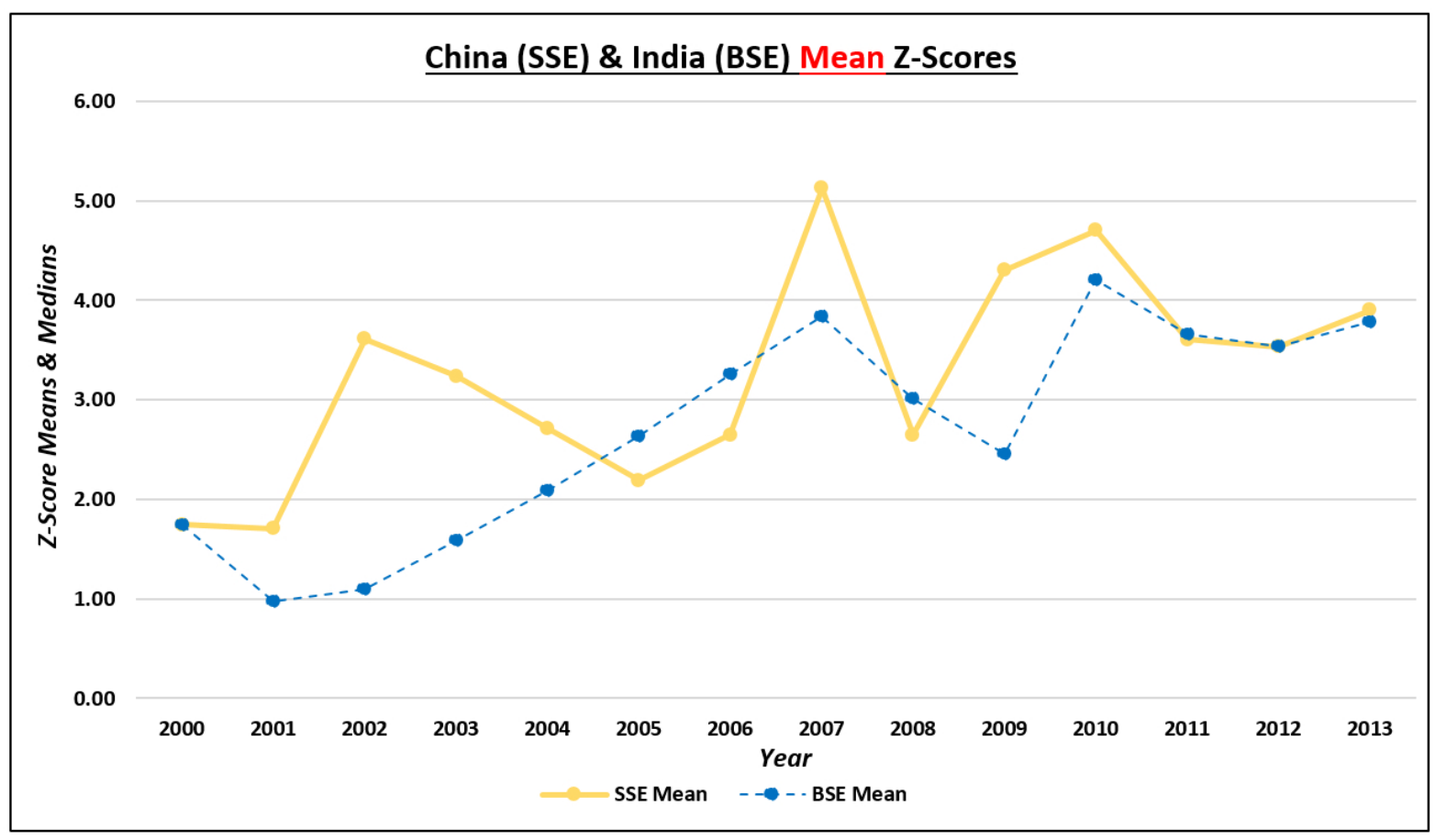

Figure 2. Mean Z-Score Trends for both markets

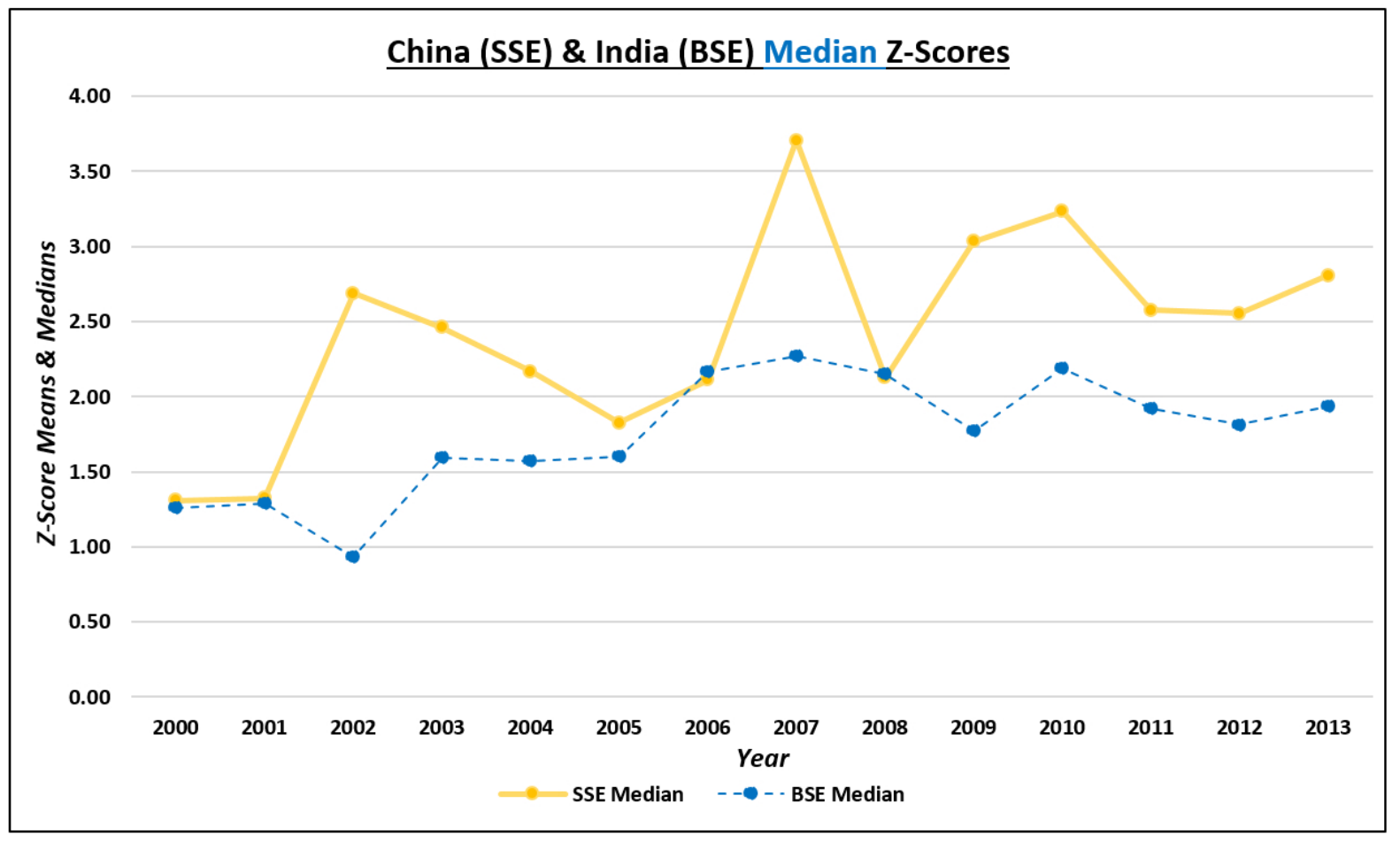

Figure 3. Median Z-Score Trends for all markets

For both markets, the overall Z-Scores for their means and medians are in the moderate-to-healthy range except for India's BSE prior to 2005. This indicates that generally, 
they are financially healthy markets, which is also aligned with their economic standings in the Asia Pacific region. China's mean and median Z-Scores tend to be higher than India's (especially median). This might be attributable to the fact that the average size of firms (e.g. market capitalization and total assets) and type of firms in China are relatively larger than the companies in India.

The median Z-Scores are considerably lower in magnitude than their mean Z-Scores for all markets. This could be similarly explained by the large variations in the size and type of firms. For both countries, the median as well as mean Z-Scores fell in tandem during the subprime crisis in 2008. They rebounded towards 2009, rising to a new peak in 2010 and again fell or stabilized in the period from 2010 to 2011 and onwards. Subsequently, the increases from 2012 to 2013 were less profound than the increases immediately after the subprime crisis, i.e. 2008 to 2010 .

The Indian BSE's mean Z-Scores ranged from 0.97 to 4.21 and its median scores ranged from 0.93 to 2.27 . This presents a medium financial health outlook overall. In all of the fourteen years, the mean Z-Scores exceeded the 1.81 lower benchmark in ten years, and it exceeded the higher 2.99 benchmark in seven years.

Additionally, the Chinese SSE's mean Z-Scores have remained within the range of 1.71 to 5.13 and its median scores ranged from 1.31 to 3.71 . This presents a significantly stronger financial health outlook than BSE's overall. During the fourteen year period, its mean Z-Scores exceeded the 1.81 lower benchmark in twelve years for the SSE, and they exceeded the higher 2.99 benchmark in eight years.

Although the corporate health for both markets has recovered from subprime crisis, they have fallen short of their previous maximum peak which was recorded around 2007. Perhaps, this reflects a longer recovery period arising from the severe subprime crisis. In summary, China's SSE seems to have fared better than India's BSE in relation to the median and mean Z-Scores for the period.

\section{Results and Interpretation}

\subsection{China (SSE)}

\begin{tabular}{r|rrrrrr}
\hline roew & Coef. & Std. Err. & $t$ & P>|t| & [95\% Conf. Interval] \\
\hline zscorew & 1.195225 & .0689961 & $\mathbf{1 7 . 3 2}$ & $\mathbf{0 . 0 0 0}$ & $\mathbf{1 . 0 5 9 9 5 8}$ & $\mathbf{1 . 3 3 0 4 9 2}$ \\
_cons & .5661635 & .3726744 & 1.52 & $\mathbf{0 . 1 2 9}$ & -.1644634 & 1.29679 \\
\hline
\end{tabular}

Figure 4. Statistical Regression Outputs - China (SSE)

A total of 4,456 observations have been used for the regression of firms in the SSE (see Figure 4). Based on these observations, the SSE has a regression coefficient of 1.195 (rounded). The standard error is close to zero, at 0.069 , whilst the t-statistic is significant and 
positive at 17.32 and the p-value is equal to zero, supporting the reliability of the regression output. This result confirms the Alternative Hypothesis by showing a positive (direction) and significant (magnitude) relationship between ROE, the dependent variable (representing corporate performance), and Z-Score, the independent variable (representing financial health).

\subsection{India (BSE)}

\begin{tabular}{r|rrrrrr}
\hline roew & Coef. & Std. Err. & $t$ & P $>|t|$ & [95\% Conf. Interval] \\
\hline zscorew & $\mathbf{. 1 1 1 5 3 3 8}$ & .0626364 & 1.78 & 0.075 & -.0113038 & .2343714 \\
_cons & $\mathbf{3 . 7 4 4 8 8 9}$ &. $\mathbf{7 8 6 8 2 1 6}$ & $\mathbf{4 . 7 6}$ & $\mathbf{0 . 0 0 0}$ & $\mathbf{2 . 2 0 1 8 3 6}$ & $\mathbf{5 . 2 8 7 9 4 1}$ \\
\hline
\end{tabular}

Figure 5. Statistical Regression Outputs - India (BSE)

A total of 2,052 observations were used for the regression analysis of the BSE exchange (see Figure 5). A regression coefficient of 0.112 has been obtained (rounded). The standard error deviation is also close to zero, at 0.063 , whilst the t-statistic is significant and positive at 1.78 and the p-value is close to zero, thus supporting the reliability of the regression output. This result also confirms the Alternative Hypothesis.

On the whole, these results show that there is indeed a statistically significant and positive relationship between firm performance and financial health in all stock exchanges. These strong positive and significant relationships between corporate performance and financial health may be construed as a positive signal for business stakeholders such as investors in these markets.

The Chinese SSE's regression coefficient is far greater than that of the Indian BSE's. This variation in coefficients could be attributable to a variety of differences in business nature and business environment, between the two markets. Firstly, the nature of the top tier of listed companies in China is mostly that of state-owned enterprises (SOEs) (Cendrowski, 2015) which may be more conducive for businesses to extract corporate performance from financial health. BSE is oldest exchange in Asia and was established in 1875 (BSE India, 2016) whereas the SSE is much younger and was established in 1990 (SSE, 2015). Additionally, the BSE has over 5,500 listings (BSE India, 2016) whereas the SSE has only 1,070 listings (SSE, 2015). However, since SSE's market capitalization of USD 3,986 billion is much larger than BSE's USD 1,682 billion (World Federation of Exchanges, 2015), SSE has fewer, newer and larger firms with a greater average market capitalization per firm.

Furthermore, China is the world's largest trading nation (Monaghan, 2014) and its economy is far more export-oriented than India's, with USD 2.21 trillion in exports as opposed to India's far lower USD 313.2 billion (2013 est.) (IndexMundi, 2013). This provides a larger, international and more diversified customer portfolio for Chinese firms to excel with. As a result, it might be reasonable to expect Chinese businesses to be better able to derive 
corporate performance from their financial health and vice versa.

\section{Limitations}

A limitation of this study is that it focuses on listed manufacturing corporations in China and India, and not on other industries. This is because we would like to align our approach with the original Altman (1968) Z-Score Model. The focus of this paper is to explore the relationships of financial health and corporate performance in the specific contexts of China and India.

\section{Future Research}

For future research, the proposed methodology can be applied to analyse the relationship between financial health and corporate performance in other markets across Asia and beyond. Other industries can be included to enhance the breadth and depth of the study. Furthermore, other variables can also be examined, and their relationships analysed.

\section{Conclusion}

We set out to explore and analyse the relationship between financial health, as measured by the Altman (1968) Z-Score, and firm performance, as measured by Return on Equity (ROE) ratios, of manufacturing companies listed in China's SSE and India's BSE. We found that there was a statistically significant and positive relationship between Return on Equity (ROE) and Altman Z-Scores in both markets. These relationships may be construed as a positive assurance for stakeholders such as investors in these markets. Comparatively, China's SSE had a significantly higher regression coefficient than India's BSE. This could be inferred as an indicator of the varying and distinct natures of the companies listed on these stock exchanges as well as the relative differences in the size of these economies. Furthermore, in our descriptive analysis, we observed generally moderate-to-healthy mean and median Z-Scores in both markets and they exhibited similar Z-Scores trends over the period.

\section{References}

Agarwal, V., \& Taffler, R. J. (2007). Twenty-five years of the Taffler z-score model: Does it really have predictive ability? Accounting and Business Research, 37(4), 285-300. http://dx.doi.org/10.1080/00014788.2007.9663313

Altman, E. I. (1968). Financial Ratios, Discriminant Analysis and The Prediction Of Corporate Bankruptcy. The Journal of Finance, 23(4), 589-609. http://dx.doi.org/10.1111/j.1540-6261.1968.tb00843.x

Altman, E. I. (1982). Accounting implications of failure prediction models. The Journal of Accountancy, 6(1), 4-19.

Altman, E. I. (2007). Revisiting credit scoring models in a Basel 2 environment. Lecture at National Taiwan University. Retrieved from www.fin.ntu.edu.tw/ hwangdar/94emba19.ppt

Altman, E. I., \& McGough, T. P. (1974). Evaluation of a company as a going-concern. The Journal of Accountancy, 143, 50-57. 
Aziz, M. A., \& Dar, H. A. (2006). Predicting corporate bankruptcy: where we stand? Corporate Governance, 6(1), 18-33. http://dx.doi.org/10.1108/14720700610649436

Beaver, W. H. (1966). Financial ratios as predictors of failure. Journal of Accounting Research, 4, 71-111. http://dx.doi.org/10.2307/2490171

Beynon, M. J., \& Peel, M. J. (2001). Variable precision rough set theory and data discretization: An application to corporate failure prediction. Omega, 29, 561-576. http://dx.doi.org/10.1016/S0305-0483(01)00045-7

Blum, M. P. (1974). Failing company discriminant analysis. Journal of Accounting Research, 12(1), 1-25. http://dx.doi.org/10.2307/2490525

BSE India. (2016). Introduction: BSE India. BSE India. Retrieved from http://www.bseindia.com/static/about/introduction.aspx?expandable $=0$

Calandro Jr, J. (2007). Considering the utility of Altman's Z-score as a strategic assessment and performance management tool. Strategy \& Leadership, 35(5), 37-43. http://dx.doi.org/10.1108/10878570710819206

Cendrowski, S. (2015). China's Global 500 companies are bigger than ever-and mostly state-owned. Fortune. Retrieved from http://fortune.com/2015/07/22/china-global-500-government-owned/

Chen, M. C., Cheng, S. J., \& Hwang, Y. (2005). An empirical investigation of the relationship between intellectual capital and firms' market value and financial performance. Journal of Intellectual Capital, 6(2), 159-176. http://dx.doi.org/10.1108/14691930510592771

Chen, S., \& Dodd, J. L. (1997). Economic Value Added (EVA $\left.{ }^{\mathrm{TM}}\right)$ : An Empirical Examination Of A New Corporate Performance Measure. Journal of Managerial Issues, 9(3), 318-333.

Chung, K. C., Tan, S. S., \& Holdsworth, D. K. (2008). Insolvency prediction model using multivariate discriminant analysis and artificial neural network for the finance industry in New Zealand. International Journal of Business and Management, 3(1), 19-29.

Cohen, B. (2006). Urbanization in developing countries: Current trends, future projections, and key challenges for sustainability. Technology in Society, 28, 69.

Damodaran, A. (2007). Return on Capital (ROC), Return on Invested Capital (ROIC) and Return on Equity (ROE): Measurement and Implications. Stern School of Business, 2-66. Retrieved from http://people.stern.nyu.edu/adamodar/pdfiles/papers/returnmeasures.pdf

Deakin, E. B. (1977). Business failure prediction: An empirical analysis. In E. Altman, \& A. Sametz (Eds.), Financial crises: Institutions and markets in a fragile environment. New York: John Wiley.

Foo, S. L. (2015). Financial Health \& Corporate Performance of Listed Manufacturing Companies in Hong Kong \& Singapore: A Comparative Study of the Two Asian Tigers. Asian Journal of Business and Management, 3(2), 148-154. 
Frydman, H. E., Altman, E. I., \& Kao, D. G. (1985). Introducing Recursive Partitioning for Financial Classification: The Case of Financial Distress. Journal of Finance, 40(1), 269-291. http://dx.doi.org/10.1111/j.1540-6261.1985.tb04949.x

Gunathilaka, C. (2014). Financial Distress Prediction: A Comparative Study of Solvency Test and Z-Score Models with Reference to Sri Lanka. The IUP Journal of Financial Risk Management, 11(3), 39-51.

Hagel, J., \& D, J. (2010). The Best Way to Measure Company Performance - HBR. Retrieved from https://hbr.org/2010/03/the-best-way-to-measure-compan.html

IndexMundi. (2013). China vs. India: Country Comparisons. IndexMundi. Retrieved from http://www.indexmundi.com/factbook/compare/china.india/economy

Koh, H. C., \& Killough, L. N. (1990). The use of multiple discriminant analysis in the assessment of the going concern status of an audit client. Journal of Business Finance \& Accounting, 17(2), 179-192. http://dx.doi.org/10.1111/j.1468-5957.1990.tb00556.x

Levitan, A. S., \& Knoblett, J. A. (1985). Indicators of exceptions to the going concern assumption. Auditing: A Journal of Practice and Theory, (Fall), 26-39.

Meric, I., Lentz, C., Li, S., \& Meric, G. (2014). A Comparison of the Financial Characteristics of Hong Kong and Singapore Manufacturing Firms. Global Journal of Business Research, $8(3), 31-37$.

Monaghan, A. (2014). China surpasses US as world's largest trading nation. The Guardian. Retrieved from http://www.theguardian.com/business/2014/jan/10/china-surpasses-us-world-largest-trading-n ation

Neophytou, E., Charitou, A., \& Charalambous, C. (2001). Predicting corporate failure: Empirical evidence for the UK. Discussion Paper No. 01-173, March, School of Management, University of Southampton, Southampton.

Ohlson, J. (1980). Financial Ratios and the Probabilistic Prediction of Bankruptcy. Journal of Accounting Research, 18(1), 109-131. http://dx.doi.org/10.2307/2490395

Perez, M. (2006). Artificial neural networks and bankruptcy forecasting: a state of the art. Neural Computer \& Application, 15, 154-163. http://dx.doi.org/10.1007/s00521-005-0022-x

Pradhan, R. (2014). Z Score Estimation for Indian Banking Sector. International Journal of Trade, Economics and Finance, 5(6), 516-520. http://dx.doi.org/10.7763/IJTEF.2014.V5.425

Shanghai Stock Exchange (SSE). (2015). Brief Intro: Shanghai Stock Exchange (SSE). Shanghai Stock Exchange (SSE). Retrieved from http://english.sse.com.cn/aboutsse/sseoverview/brief/

Sherbo, A., \& Smith, A. (2013). The Altman Z-Score Bankruptcy Model at Age 45: Standing the Test of Time? ABI Journal, 32(11), 40-42. 


\section{Macrothink}

Journal of Asian Development

ISSN 2377-9594

2016, Vol. 2, No. 1

Stowe, J. D., Robinson, T. R., Pinto, J. E., \& McLeavey, D. W. (2002). Analysis of Equity Investments: Valuation. Baltimore, MD: Association for Investment Management and Research (AIMR).

Thai, S., Goh, H., Teh, B., Wong, J., \& Ong, T. (2014). A Revisited of Altman Z- Score Model for Companies Listed in Bursa Malaysia. International Journal of Business and Social Science, 5(12), 197-207.

Trippi, R. R., \& Turban, E. (1996). Neural networks in finance and investing: using artificial intelligence to improve real-world performance (pp. 367-394). London: IRWIN Professional Publishing, 367-394.

Wang, Y., \& Campbell, M. (2010). Business Failure Prediction For Publicly Listed Companies In China. Journal of Business and Management, 16(1), 75-88.

Wang, Y., \& Campbell, M. (2010). Do Bankruptcy Models Really Have Predictive Ability? Evidence Using China Publicly Listed Companies. International Management Review, 6(2), 77.

World Federation of Exchanges. (2015). Monthly Reports. World Federation of Exchanges. Retrieved from http://www.world-exchanges.org/home/index.php/statistics/monthly-reports

Zhao, Y. (2013). The Relationship between Share Price Gains, Corporate Performance and Risk. OALib Journal, 110-112. Retrieved from http://www.oalib.com/paper/2993772

\section{Copyright Disclaimer}

Copyright reserved by the authors.

This article is an open-access article distributed under the terms and conditions of the Creative Commons Attribution license (http://creativecommons.org/licenses/by/3.0/). 